\title{
THE MATHEMATICAL CRITICAL THINKING OF MTs STUDENTS IN SOLVING MATH PROBLEMS
}

\author{
Anike Putri
}

Pesantren Teknologi Riau, INDONESIA

\section{ARTICLE'S INFORMATION}

\section{Article history:}

Received: Nov-28-2020

Accepted: Dec-30-2020

\section{Keywords: Mathematical Critical Thinking Skills, Problem Solving}

\section{Corresponding address:}

Anike Putri,

\begin{abstract}
The purpose of this descriptive qualitative research was to provide a description of the mathematical critical thinking skills of MTs students in solving mathematical problems, more precisely in the context of a flat side room shape. The research subjects were selected based on the UTS Math score. Subjects who were Grade VIII students of the Riau Technology Islamic Boarding School were grouped into high, medium, and low mathematical abilities. From each group, one student who has good communication skills is chosen as the research subject. After giving tests and interviews to the three subjects, the results obtained showed that the average test for each indicator of mathematical critical thinking skills at the inference stage reached 96.83 , the analysis stage reached 88.33 , the evaluation stage reached 79.33 and the inference stage reached 59.83. Each subject has different critical thinking skills according to the indicators of mathematical critical thinking skills.
\end{abstract}

E-mail:anikeputri10.ap@gmail.com

\section{INTRODUCTION}

Based on the regulation of the minister of education and culture, positive attitude in mathematics, namely: logical, critical, careful and thorough, honest, responsible, and not easy to give up in solving problems, as a form of implementing habits in mathematical inquiry and exploration must be shown in content standards primary and secondary education students [1]. This regulation is in line with the opinion of Henra Saputra, who stated that the ability to think critically is one of the hard skills that are required to exist in the current curriculum and 21st century competencies [2]. The ability to think critically in the 2013 Curriculum is very much needed by students. The reason is because science and technology are currently experiencing rapid development so that it can enable anyone to obtain information quickly and easily with the availability of various abundant sources from anywhere in the world.

The development of information and technology has an impact on changes in the order of life and global changes in life. Thus, an important ability that every individual must have in this era of globalization is critical thinking [3] [4]. Critical thinking is needed as a provision to filter whether an information deserves to be accepted or rejected [5].

Human resources with good problem-solving abilities to deal with various life problems are also very much needed in the era of globalization. Someone who has high abilities must be able to think logically, rationally, critically and creatively [6]. Therefore, students need to be equipped with critical thinking skills so that they are able to process, assess and retrieve the information needed to deal with the problems at hand.

The ability to think critically is very important to be instilled from an early age, namely in schools, homes and in the community. Critical thinking is a directed process with clarity that is used 
in systematic mental activities, such as solving problems, making decisions, persuading, analyzing assumptions and conducting scientific research conducted by tolerant people with open minds to expand their understanding [7]. Facione divides critical thinking skills into six categories consisting of interpretation, analysis, evaluation, inference, explanation, and self-regulation [8].

The ability to think critically is a very important part of the mathematics learning process. This is because it can shape students to think critically, master mathematical concepts thoroughly and obtain satisfactory grades. Critical thinking is a characteristic that is considered important to be taught and can be developed through mathematics learning because mathematics has a strong and clear structure and linkages between its concepts [9].

Syarif also stated in his opinion that mathematical critical thinking is needed by students when they are faced with challenges, namely by considering the information received, making plans, determining decisions to be taken, making decisions, and evaluating [10]. Meanwhile Chukwuyenum explained that critical thinking skills are an effective way to increase students' understanding of mathematical concepts [11]. This is because mathematical critical thinking skills can help students to interpret, analyze, evaluate and present dates in a logical and sequential manner. Mathematical critical thinking skills are the ability to think naturally and effectively, focusing on concentrating what should be believed or done, with indicators consisting of interpretation, analysis, evaluation and inference.

Indicators of mathematical critical thinking skills used in this study are interpretation, analysis, evaluation and inference. The interpretation indicator is that students are required to be able to understand the problem, which is shown by writing "known" as they know how to represent the background of question before they finally solve the problem correctly. Indicator analysis is that students can identify the relationships between the statements, questions, and concepts given in the questions, which is shown by making a mathematical model and giving an appropriate explanation. The evaluation indicator is that students can use the right strategy in solving questions, completely and correctly in making calculations. The last one is an inference indicator, where the ability of students to be able to make conclusions correctly. One of the studies related to mathematical critical thinking was conducted by Mullis, et al. In his research on the analysis of the Trends in Mathematics and Science Study (TIMSS) study in 2007 and 2011, he found that the learning achievement scores of grade VIII junior high school students were 397 and 386, respectively. These findings are not much different from the findings in the 2015 TIMSS results which show that the achievement of Indonesian students in the field of mathematics is ranked 45 out of 50 countries with a score of 397. These results do not show much change in each of their participation. TIMSS's low performance results are of course caused by several factors. Indonesian students are less trained in solving contextual problems, demanding reasoning, argumentation and creativity as well as critical thinking in solving these questions are factors that cause the low scores obtained. Niluh explains in terms of mathematical content that geometry is one of the topics in TIMSS that needs to be further improved [12].

The subjects of this study were students who had high, medium, and low mathematical abilities. This is based on the tendency of schools in Indonesia to group students in one class heterogeneously because heterogeneous grouping of students will increase student achievement. Thus it is expected that the selection of this subject can provide an overview of the representation ability of students at each level of ability. 


\section{METHODS}

This research is a descriptive qualitative research conducted at MTs in Riau Province. These MTs has not shown any achievements in the academic field, but the students' abilities in the productive field have been recognized and recognized by the community as well as the business world and industry around the school environment.

The research begins by determining the research subject through preliminary observations. Researcher observed the Mathematics UTS scores of 30 students of class VIII at MTs and grouped them into high, medium, and low mathematical ability categories. After this grouping, each student who has the best communication from each category is chosen to be the research subject. The researcher then creates a code that represents each research subject which aims to facilitate and simplify the analysis. The code made is ST for subjects with high mathematical abilities, SS for subjects with moderate mathematical abilities, and SR for subjects with low mathematical abilities.

The next research stage was to ask students of class VIII MT's to solve the problems given by the researcher within 15 minutes. The problems given are as presented in Figure 1. The researcher asked students to solve the problem in any way they want. For example, students can tell what they did to find a solution to the problem, by drawing or using mathematical expressions, or in other ways as long as students write down the complete steps for solving them.

\section{Problem 1}

Indonesia's tourism ministry has a plan to make a replica of the pyramid. It is planned that the pyramid will be made with a square base with sides of $8 \mathrm{~m}$ and height of a triangle with sides of $6 \mathrm{~m}$. If the replica is covered with tiles size $40 \mathrm{~cm} \times 40 \mathrm{~cm}$, how many tiles are needed?

a. Based on the illustration of the questions above, make what is known and asked!

b. Make a mathematical model to solve the above problems!

c. Make a strategy to solve the problems above!

d. Summarize vour answer!

Figure 1. The problem given to the subject

After students solve the problem, the researcher conducted an interview with the three predetermined subjects in turn in order to obtain valid data and reveal the subject's way of thinking. This is because it is less observable if only viewed from the results of the subject's work. From the results of work and interviews with each subject, an analysis of the subject's mathematical critical thinking ability was carried out by referring to the indicators given in Table 1 . The rubric for assessing critical thinking skills according to Facione [8] can be seen in Table 1 below:

Table 1.Critical Thinking Ability Test Score Rubric

\begin{tabular}{|c|c|c|}
\hline Indicator & Description & Score \\
\hline \multirow[t]{5}{*}{ Interpretation } & Not writing what is known and asked. & 0 \\
\hline & Writing what is known and asked incorrectly. & 1 \\
\hline & Writing what is known only correctly or what is asked only correctly. & 2 \\
\hline & Writing what is known from the questions correctly but less complete. & 3 \\
\hline & $\begin{array}{l}\text { Writing what is known and asked from the questions correctly and } \\
\text { completely. }\end{array}$ & 4 \\
\hline \multirow[t]{3}{*}{ Analysis } & Not making Mathematics model from the question given. & 0 \\
\hline & Making Mathematics model from the question given but incorrectly. & 1 \\
\hline & $\begin{array}{l}\text { Making Mathematics model from the question given correctly without } \\
\text { giving explanation }\end{array}$ & 2 \\
\hline
\end{tabular}




\begin{tabular}{|c|c|c|}
\hline Indicator & Description & Score \\
\hline & $\begin{array}{l}\text { Making Mathematics model from the questions given correctly but there is } \\
\text { mistake in the explanation }\end{array}$ & 3 \\
\hline & $\begin{array}{l}\text { Making Mathematics model from the question given correctly and giving } \\
\text { correct and complete explanation. }\end{array}$ & 4 \\
\hline \multirow[t]{5}{*}{ Evaluation } & Not using strategy in solving the question. & 0 \\
\hline & Using incorrect and incomplete strategy in solving the questions. & 1 \\
\hline & $\begin{array}{l}\text { Using correct strategy in solving the question, but incomplete or using } \\
\text { incorrect strategy but complete in solving the question. }\end{array}$ & 2 \\
\hline & $\begin{array}{l}\text { Using correct strategy in solving the question, complete but doing mistake } \\
\text { in the calculation or explanation. }\end{array}$ & 3 \\
\hline & $\begin{array}{l}\text { Using correct strategy in solving the question, complete and correct in } \\
\text { doing the calculation/explanation. }\end{array}$ & 4 \\
\hline \multirow[t]{5}{*}{ Inference } & Not making the conclusion. & 0 \\
\hline & Making incorrect conclusion and not suitable with the question context. & 1 \\
\hline & $\begin{array}{l}\text { Making incorrect conclusion even though it is not in accordance with the } \\
\text { question context. }\end{array}$ & 2 \\
\hline & Making correct conclusion, in accordance with the context but incomplete. & 3 \\
\hline & $\begin{array}{l}\text { Making conclusion correctly, suitable with the question context and } \\
\text { complete. }\end{array}$ & 4 \\
\hline
\end{tabular}

The test scores obtained were classified based on the criteria for classifying mathematical critical thinking abilities. It is as presented in Table 2 below.

Table 2 Criteria for Classification of Mathematical Critical Thinking Ability

\begin{tabular}{cc}
\hline Persentase (\%) & Kategori \\
\hline $86-100$ & Very Good \\
$76-85$ & Good \\
$60-75$ & Enough \\
$55-59$ & Less \\
$<54$ & Very Less \\
\hline \multicolumn{2}{c}{ Adaptation: Purwanto, 2012 }
\end{tabular}

Based on Table 2, the learning device is said to be effective if the minimum mathematical critical thinking ability test score is in good criteria.

\section{RESULTS AND DISCUSSION}

The researcher observed that of the 30 students who participated in this study, they used different mathematical critical thinking skills for a given problem. This test aims to assess the quality of the learning tools used in terms of effectiveness. The recapitulation of test results related to mathematical critical thinking skills is shown in Table 3 below:

Table 3. Recapitulation of Mathematical Critical Thinking Ability Test Results

\begin{tabular}{lc}
\hline & Post test \\
\hline The highest score & 93,75 \\
The lowest score & 50,00 \\
The average test score of each indicator & \\
a. Interpretation & 96,83 \\
a. Analysis & 88,33 \\
b. Evaluation & 79,33 \\
c. Inferences & 59,83 \\
The average score of Mathematical Critical Thinking Skill & 81,08 \\
\hline
\end{tabular}


Referring to the results presented in Table 3 above, the average value of mathematical critical thinking skills reaches 81.08 and is included in the good criteria. The average test on each indicator of mathematical critical thinking ability based on Table 3 is that the inference stage reaches 96.83, the analysis stage reaches 88.33 , the evaluation stage reaches 79.33 and the inference stage reaches 59.83. Guided by the criteria for categorizing critical thinking skills in Table 2, each indicator of mathematical critical thinking skills can be described.At the interpretation stage, the category obtained has met the very good category, which means that students can understand the problem, which is shown by writing "know" to explain about the background of the problems before they finally answer the questions being asked correctly. The analysis stage fulfills the very good category which indicates that students are able to identify the relationships between the statements, questions, and concepts given in the questions. This ability is demonstrated by making mathematical models appropriately and well explained.

Next is the evaluation stage. This stage reaches the good category. This means that students are able to use the right strategy in solving the questions completely and correctly in carrying out the calculations. The average of the inference stage meets the sufficient category. This indicates that there are some students who do not draw conclusions correctly. Based on the criteria for categorizing the final test of critical thinking skills, overall it is stated that it has met the good classification. The following will provide a description of students' mathematical critical thinking skills with high, medium, and low mathematical abilities.

1. Mathematical Critical Thinking Ability in Subjects with High Mathematical Ability (ST)

In the ST category, they already have good critical thinking skills because ST is able to classify questions consisting of knowing, asking and making mathematical models, namely considering the formula for the area of a triangle, solving problems well, but not making conclusions from the problems given. ST's answer is presented in Figure 2 below.

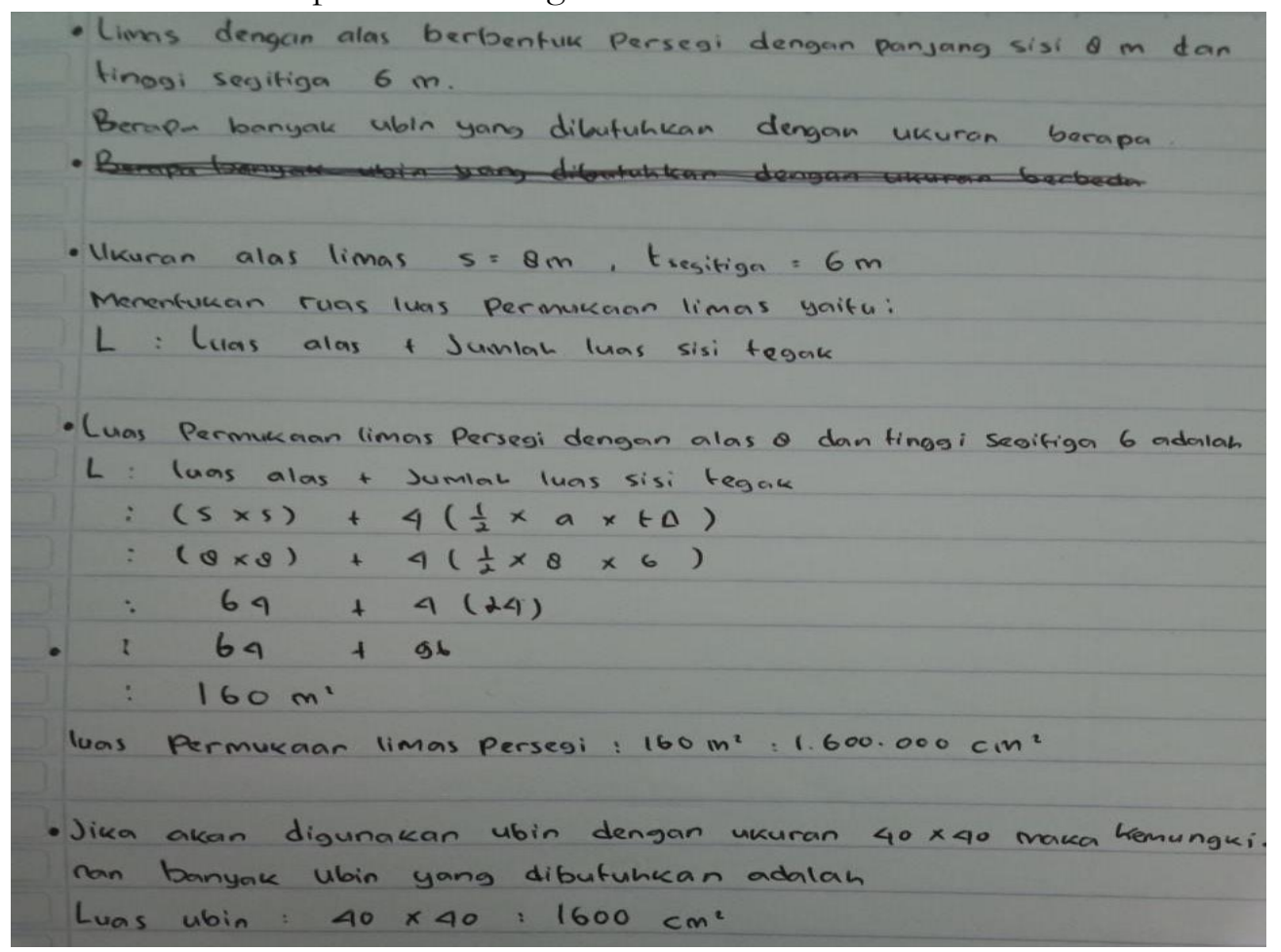

Figure 2. Answer Made by Category with ST Category

Figure 2 presents the work of students in solving problems. Students are able to interpret the 
questions well by making "known, asked and answered" and making strategies to solve the problems given. Students are able to analyze the problem properly when they make a mathematical model that fits the problem. Students in this case have also been able to make good evaluations by solving questions correctly and correctly. However, students have not inferred well because they did not provide conclusions that were tailored to the context of the questions. Based on the results of the analysis of students' answers, it can be seen that students have high mathematical critical thinking skills.

\section{Mathematical Critical Thinking Ability in Subjects with Moderate Mathematical Ability (SS)}

In the SS category, students already have good critical thinking skills, because they are able to classify questions by knowing, asking and making mathematical models, namely considering the formula for the area of a triangle. But in this case they have not resolved the problem properly and did not make any conclusions from the problems given. The answers given by students in the SS category can be seen in Figure 3 below.

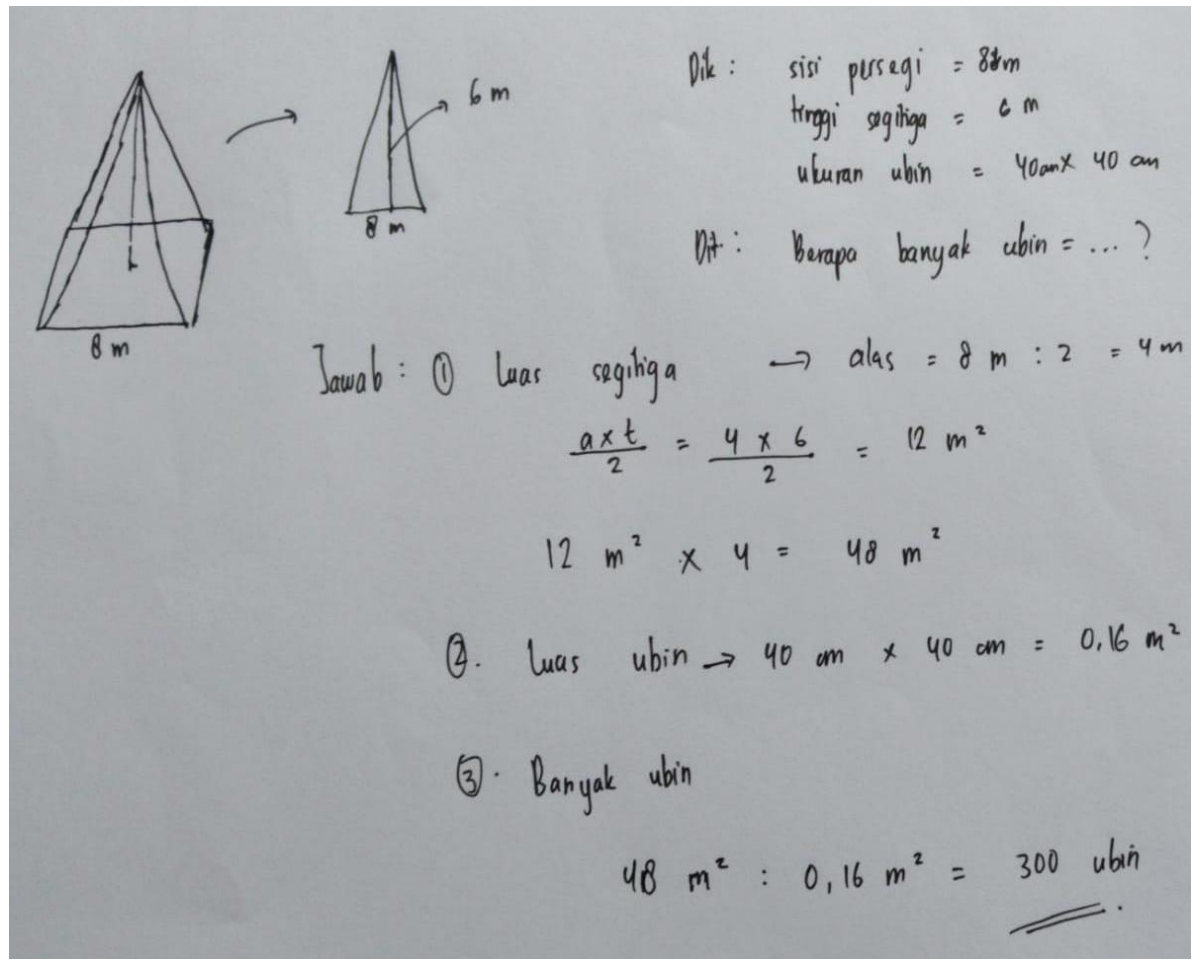

Figure 3. Answer Made by Student with SS category

Figure 3 shows that students can interpret the questions well by making it known, asked and answered. In addition, they also make strategies to solve the problems given. However, students have not been able to provide a good question analysis because the mathematical model they made does not match the answer to the problem, namely making the formula for the surface area of a pyramid. Students have not been able to evaluate properly where they only calculate the 4 areas of the triangle which should be followed by calculating the area of the pyramid base which is square and adding up the areas of both. Students have not inferred the questions well because they did not make conclusions that were adapted to the context of the questions. Based on the results of the analysis of the students' answers, it was concluded that students had moderate mathematical critical thinking skills. 
3. Mathematical Critical Thinking Ability in Subjects with Low Mathematical Ability (SR)

Students in the SR category indicate that they do not have good critical thinking skills, because SR cannot make known, asked and incorrectly make mathematical models and do not make conclusions from the problems given. The SR answer can be seen in Figure 4 below.

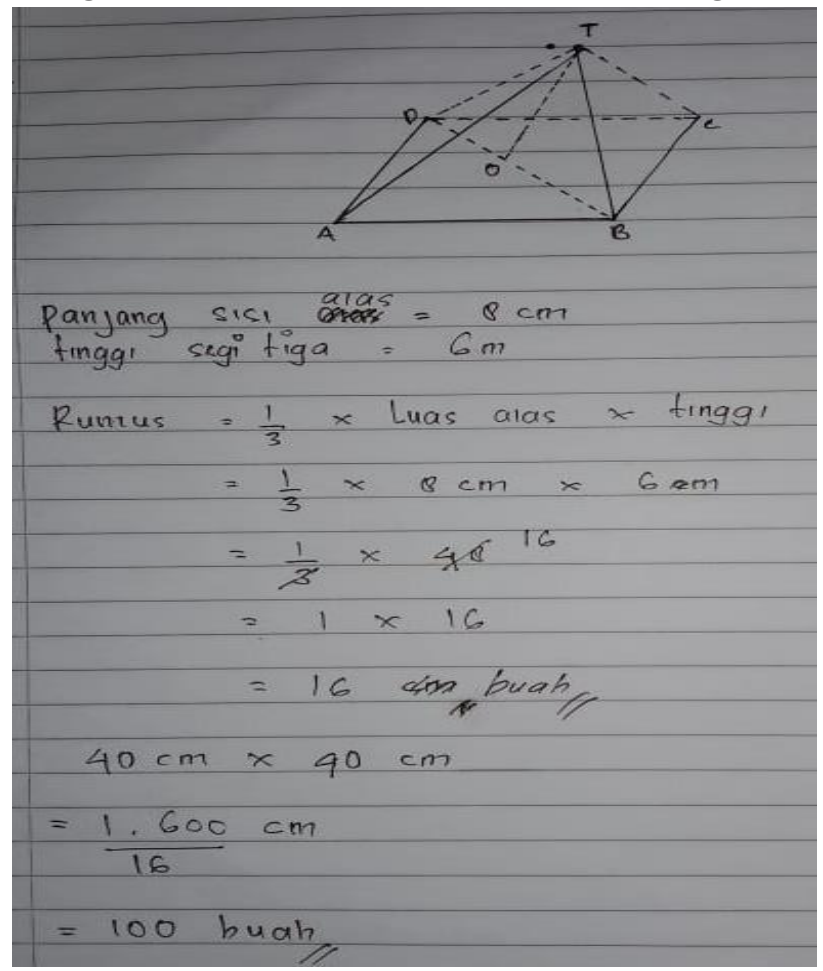

Figure 4. Representations Made by SR

Figure 4 shows that students cannot interpret the questions because they cannot represent the questions by making it known, asked and answered. Apart from that they also make the wrong strategy to solve the given problem. Students use the cone volume formula while what is needed is the surface area of the pyramid. Thus the analysis provided by students is not correct because they do not make a mathematical model that is appropriate to the problem. Students have not been able to evaluate properly because they are wrong in using the formula so that the students' answers are also wrong. Students have not inferred well because they did not make conclusions that were adapted to the context of the questions. Based on the results of the analysis of the students 'answers, it can be concluded that the students' mathematical critical thinking skills are low.

\section{CONCLUSIONS AND SUGGESTIONS}

The results of the analysis of students 'answers based on the results of the study were concluded as follows: The average test for each indicator of students' mathematical critical thinking skills consisting of the inference stage, the analysis stage, the evaluation stage, and the inference stage respectively reached $96.83,88.33,79.33$ and 59.83. Subjects with high mathematical critical thinking skills can make inference, analysis, evaluation but not inference according to the context of the question. Subjects with moderate mathematical critical thinking ability are able to make inferences but have not been able to make proper analysis and evaluation and do not make appropriate inferences in the context of the question. The latter is a subject with low mathematical critical thinking skills, they are unable to make appropriate inferences, analyzes and evaluations. In addition, they are also unable to make inferences according to the context of the problem. 


\section{REFERENCE}

[1] Permendikbud, "Nomor 21 tahun 2016 tentang Standar Isi Pendidikan Dasar dan Menengah," 2016.

[2] H. S. Tanjung and S. A. Nababan, "Pengembangan Perangkat Pembelajaran Matematika Berorientasi Model Pembelajaran Berbasis Masalah (PBM) Untuk Meningkatkan Kemampuan Berpikir Kritis Siswa Sma Se-Kuala Nagan Raya Aceh," Genta Mulia, vol. 9, no. 2, pp. 56-70, 2018.

[3] E. Aizikovitsh-Udi and D. Cheng, "Developing Critical Thinking Skills from Dispositions to Abilities: Mathematics Education from Early Childhood to High School," Creat. Educ., vol. 6, pp. 455-462, 2015.

[4] C. Kriel, "Creating a Disposition for Critical Thinking in the Mathematics Classroom," in Proceedings of the Second Biennial Conference of the South African Society for Engineering Education, 2013.

[5] A. R. As'ari, "Ideas for Developing Critical Thinking at Primary School Level," in International Seminar on Addressing Higher Order Thinking: Critical Thinking Issues in Primary Education, 2014.

[6] I. H. Abdullah, "Berpikir Kritis Matematik," J. Pendidik. Mat., vol. 2, no. 1, pp. 66-75, 2013.

[7] E. B. Johnson, Contextual teaching \& learning. Bandung: Kaifa, 2009.

[8] P. A. Facione, "Critical Thinking: A Statement of Expert Consensus for Purposes of Educational Assessment and Instruction Executive Summary “ The Delphi Report," 1990.

[9] A. J. Nitko, "Educational Assessment of Students (6th Ed)," in eText with Loose-Leaf Version -Access Card Package, Boston: Pearson, 2011.

[10] M. Syarif, "Pembelajaran dengan Pendekatan Problem Solving untuk Meningkatkan Kemampuan Berpikir Kritis dan Kreatif Matematika Peserta Didik SMA," Pas. J. Math. Educ., vol. 6, no. 1, pp. 56-75, 2016.

[11] A. N. Chukwuyenum, "Impact of Critical thinking on Performance in Mathematics among Senior Secondary School Students in Lagos State," IOSR J. Res. Method Educ., vol. 3, pp. 1825, 2013.

[12] N. Sulistyani, "Pengembangan Lembar Kegiatan Siswa (LKS) Bangun Ruang Sisi Datar Berbasis PBL," J. Mat., vol. 6, no. 1, pp. 23-33, 2016.

\section{BIOGRAPHY}

Anike Putri

She obtained her Strata-2 (S2) Mathematics Education in Universitas Riau. E-mail : anikeputri10.ap@gmail.com 